\title{
PERBEDAAN EFEK EKSTRAK BUAH NAGA MERAH (Hylocereus polyrhizus) DAN EKSTRAK BUAH NAGA PUTIH (Hylocereus undatus) TERHADAP KADAR KOLESTEROL TOTAL TIKUS PUTIH (Rattus norvegicus)
}

\section{(Difference effects of red dragon fruit extract [Hylocereus Polyrhizus] and white dragon fruit extract [Hylocereus Undatus] to total cholesterol level in white rats [Rattus Norvegicus])}

\author{
Luthfi Octafyan Prakoso ${ }^{1 *}$, Hany Yusmaini ${ }^{2}$, Maria Selvester Thadeus ${ }^{3}$, Sugeng Wiyono ${ }^{4}$ \\ 'Progam Studi Sarjana Kedokteran, UPN "Veteran" Jakarta, Jakarta 12450 \\ ${ }^{2}$ Departemen Farmakologi, Fakultas Kedokteran, UPN "Veteran" Jakarta, Jakarta 12450 \\ ${ }^{3}$ Departemen Patologi Anatomi, Fakultas Kedokteran UPN "Veteran” Jakarta, Jakarta 12450 \\ ${ }^{4} J u r u s a n$ Gizi, Poltekkes Kemenkes Jakarta II, Jakarta 12120
}

\begin{abstract}
This study aimed to compare the effect of red dragon fruit extract (Hylocereus polyrhizus) and white dragon fruit extract (Hylocereus undatus) to total cholesterol levels in white rats (Rattus norvegicus). Total of 30 males white wistar strains were divided into five treatments i.e: (1) standard feed and NaCMC $1 \%$ (K1), (2) standard feed and quail egg $10 \mathrm{ml} / \mathrm{kgBW}(\mathrm{K2})$, (3) standard feed, quail egg $10 \mathrm{ml}$ $\mathrm{kgBW}$ and simvastatin dose 0,72mg/day (P1), (4) standard feed, quail egg $10 \mathrm{ml} / \mathrm{kgBW}$ and red dragon fruit extract dose $60 \mathrm{mg} / 200 \mathrm{gBW} /$ day (P2), (3) standard feed, quail egg $10 \mathrm{ml} / \mathrm{kgBW}$ and white dragon fruit extract dose $120 \mathrm{mg} / 200 \mathrm{gBW} /$ day (P3). The intervention was carried out for 14 days after 7 days acclimatization period. Data was analyzed by One Way ANOVA test and continued with Post Hoc Bonferroni test $(p=0.05)$. In P2 group, there was a difference of total blood cholesterol level by 25.83 $m g / d l$ compared with the positive control group and statistically significant $(p<0.05)$. In P1 and P3 group there were difference in cholesterol levels of $9.5 \mathrm{mg} / \mathrm{dl}$ and $11.5 \mathrm{mg} / \mathrm{dl}$ compared with the positive control group, but not statistically significant $(p>0.05)$. The comparison between red dragon extract group and white dragon extract showed a non-significant difference $(p>0.05)$. Red dragon fruit extract and white dragon extract have a potential effect to improve hypercholesterolemia conditions.
\end{abstract}

Keywords: Rattus norvegicus, red dragon fruit extract, total cholesterol, white dragon fruit extract

\begin{abstract}
ABSTRAK
Penelitian ini bertujuan mengetahui perbedaan pemberian efek ekstrak buah naga merah (Hylocereus polyrhizus) dan ekstrak buah naga putih (Hylocereus undatus) terhadap kadar kolesterol total pada tikus putih (Rattus norvegicus). Sebanyak 30 ekor tikus putih jantan galur wistar, dikelompokkan menjadi lima kelompok, yaitu (1) pakan standar dan Na-CMC 1\%(K1), (2) pakan standar dan telur puyuh 10ml/ $\mathrm{kg} / \mathrm{bb}(\mathrm{K} 2)$, (3) pakan standar, telur puyuh 10ml/kgbb dan Simvastatin dosis 0,72mg/hari (P1), (4) pakan standar, telur puyuh $10 \mathrm{ml} / \mathrm{kgbb}$ dan ekstrak buah naga merah dosis $60 \mathrm{mg} / 200 \mathrm{~g} \mathrm{bb} / \mathrm{hari}(\mathrm{P} 2)$, (5) pakan standar, telur puyuh $10 \mathrm{ml} / \mathrm{kgbb}$ dan ekstrak buah naga putih dosis $120 \mathrm{mg} / 200 \mathrm{~g} \mathrm{bb} / \mathrm{hari}$ (P3). Intervensi dilakukan selama 14 hari setelah masa aklimatisasi selama 7 hari. Analisis data menggunakan uji One Way ANOVA dan dilanjutkan dengan uji Post Hoc Bonferroni $(\mathrm{p}=0,05)$. Pada kelompok P2 terdapat perbedaan kadar kolesterol total sebesar $25,83 \mathrm{mg} / \mathrm{dl}$ dibandingkan dengan $\mathrm{K} 2$ dan bermakna secara statistik $(\mathrm{p}<0,05)$. Pada kelompok P1 dan P3 terdapat perbedaan kadar kolesterol total sebesar 9,50 mg/dl dan 11,5 mg/dl dibandingkan dengan K2, namun tidak bermakna secara statistik $(\mathrm{p}>0,05)$. Perbandingan antara kelompok ekstrak naga merah dengan ekstrak naga putih menunjukkan perbedaan yang tidak bermakna $(\mathrm{p}>0,05)$. Ekstrak buah naga merah dan ekstrak naga putih memiliki efek potensial dalam memperbaiki kondisi hiperkolesterolemia.
\end{abstract}

Kata kunci: ekstrak buah naga merah, ekstrak buah naga putih, kolesterol total, Rattus norvegicus

$\overline{\text { *Korespondensi: Telp: }}+6281380721010$, Surel: luthfi.octafyan@gmail.com 
Prakoso dkk.

\section{PENDAHULUAN}

Penyakit jantung koroner telah menjadi pembunuh nomor satu di dunia yang termasuk dalam kelompok penyakit kardiovaskular saat ini (WHO 2009). Terdapat beberapa faktor risiko terkait kejadian penyakit jantung koroner, antara lain adalah merokok, kadar kolesterol tinggi, tekanan darah tinggi, aktivitas fisik rendah, obesitas, diabetes mellitus (AHA 2016).

Tingginya kadar kolesterol telah menjadi penyebab utama timbulnya penyakit jantung koroner dan stroke, baik pada negara maju maupun berkembang (WHO 2009). Individu dengan kadar kolesterol total tinggi $(>260 \mathrm{mg} / \mathrm{dl})$ mempunyai risiko dua kali terkena penyakit jantung koroner dibanding dengan individu dengan kadar kolesterol normal. Populasi dengan harapan hidup baik dan insiden penyakit kardiovaskular yang rendah mempunyai nilai kolesterol rata-rata dalam batas 160-180 mg/dl (Wiyono et al. 2004).

Prevalensi kadar kolesterol yang tinggi, terjadi lebih banyak pada wilayah Eropa (54\%), diikuti wilayah Amerika (48\%), dan wilayah Asia Tenggara (39\%). Negara berpenghasilan tinggi dilaporkan memiliki kejadian hi-perkolesterolemia yang lebih besar dibandingkan negara dengan penghasilan rendah (WHO 2009).

Masyarakat Indonesia telah banyak memanfaatkan berbagai jenis tanaman yang dapat digunakan sebagai alternatif untuk menunjang kesehatan, namun sebagian masyarakat Indonesia belum sepenuhnya mengetahui jenis, manfaat ataupun cara penggunaan tanaman obat tersebut (Syarif et al. 2011).

Salah satu jenis buah yang sudah banyak dimanfaatkan di Indonesia adalah Buah Naga (Hylocereus sp.). Selain rasanya yang enak dan cukup digemari masyarakat, beberapa penelitian menyatakan bahwa buah naga memiliki khasiat untuk kesehatan manusia (Kristanto 2014). Buah naga memiliki kandungan zat yang baik untuk tubuh, khususnya zat yang berperan untuk menurunkan kadar kolesterol total darah, seperti senyawa antioksidan (fenol, flavonoid, vitamin $\mathrm{C}$ dan betasianin), vitamin B3 (niasin), serat, MUFA (monounsaturated fatty acid), dan PUFA (polyunsaturated fatty acid) (Pareira 2010).

Buah naga merah memiliki kandungan vitamin C, vitamin B3 (niasin), serat dan betasianin yang lebih tinggi dibandingkan buah naga putih (Mahattanatawee et al. 2006; Tang \& Norziah 2007; Choo \& Yong 2011, Pareira 2010 ; Liniawati 2011). Sedangkan buah naga putih memiliki kandungan fenol dan asam lemak tidak jenuh (MUFA dan PUFA) yang lebih tinggi dibanding- kan buah naga merah (Ariffin et al. 2009 ;Choo \& Yong 2011).

Uji skrining fitokimia didapatkan bahwa buah naga merah dan buah naga putih memiliki kandungan fitokimia seperti alkaloid, saponin dan titerpenoid, dimana senyawa tersebut memiliki peran dalam menurunkan kadar kolesterol darah (Bogoriani 2015 ; Warditiani et al. 2015 ; Budiarto et al. 2016).

Penelitian terdahulu menunjukkan bahwa pemberian ekstrak etanol buah naga merah dengan dosis $60 \mathrm{mg} / 200 \mathrm{gBB} / \mathrm{hari}$ mampu menurunkan kolesterol total sebesar 63,33\% (Indriasari 2012). Penelitian yang dilakukan oleh Pareira pada tahun 2010 menunjukkan bahwa jus buah naga putih dosis $10,8 \mathrm{~g} / 200 \mathrm{gBB} /$ hari mempunyai efek menurunkan kadar kolesterol total darah yang tidak berbeda secara signifikan dengan simvastatin dosis terapi (Pareira 2010).

Bedasarkan perbedaan kandungan kadar zat diantara kedua jenis spesies buah naga, dan penelitan terdahulu, maka peneliti tertarik untuk membandingkan efek kedua jenis buah naga dalam menurunkan kadar kolesterol total darah.

\section{METODE}

\section{Desain, tempat, dan waktu}

Penelitian ini merupakan penelitian true experimental pada tikus putih galur wistar dengan rancangan penelitian post-test only control group design. Penelitian ini dilakukan di Laboratorium Departemen Farmakologi dan Terapi Fakultas Kedokteran Universitas Padjajaran, Bandung. Ekstrak buah naga merah dan ekstrak buah naga putih dibuat di Balai Penelitian Tanaman Rempah dan Obat (BALITTRO), Bogor, Jawa Barat (No.Adm. : 64/T/LAB/I/17). Penelitian ini dilaksanakan pada bulan Juli 2016-Juli 2017 dengan waktu intervensi selama 14 hari.

\section{Jumlah dan cara pengambilan sampel}

Besar sampel tiap kelompok dihitung menggunakan rumus Federer dengan dengan $\mathrm{n}$ adalah jumlah sampel, dan $t$ adalah jumlah kelompok. Rumus yang digunakan adalah sebagai berikut :

$$
(\mathrm{n}-1)(\mathrm{t}-1) \geq 15
$$

Bedasarkan rumus tersebut maka jumlah minimal yang dibutuhkan adalah lima ekor tikus tiap kelompok. Namun, untuk menghindari berkurangnya jumlah sampel selama masa penelitian, maka peneliti menambahkan kriteria dropout pada masing-masing kelompok, sehingga ti- 
kus yang digunakan dalam penelitian ini adalah 30 ekor tikus (Rattus norvegicus).

Penelitian ini telah mendapatkan persetujuan etik dari Komisi Etik Penelitian Kesehatan Universitas Pembangunan Nasional "Veteran" Jakarta No : B/830/II/2017/KEPK.

\section{Bahan dan alat}

Bahan baku ekstrak buah naga diperoleh dari pasar lokal dan merupakan buah naga impor yang berasal dari Binh Thuan, Vietnam. Hewan coba yang digunakan dalam penelitian ini adalah 30 ekor tikus putih jantan galur wistar berusia 8 minggu dengan berat badan 150-250 g. Tikus putih jantan galur wistar diperoleh dari Laboratorium Farmakologi dan Terapi Fakultas Kedokteran Universitas Padjajaran, Bandung.

Bahan lain yang digunakan dalam penelitian ini adalah Simvastatin, Na-CMC (Carboxymethyl Cellulose), aquadest, telur puyuh, dan pakan standar Bravo-512. Pemilihan pakan standar Bravo-512 didasarkan pada kemudahan akses mendapatkannya, serta kemiripan persentase kandungan zat gizi dalam pakan tersebut dengan pakan standar lainnya (Agustina 2014).

Alat yang digunakan antara lain adalah kandang hewan coba yang dilengkapi botol minum dan kawat jaring sebagai tempat menaruh pakan, timbangan elektrik, disposible syringe, sonde lambung, beker glass, tabung reaksi, spidol, kertas label, skapel, mikropipet, kapas, alkohol 70\%, sarung tangan, reagen-kit kolesterol, dan spektrofotometer.

\section{Tahapan penelitian}

Pembuatan ekstrak dan dosis intervensi.

Ekstrak buah naga merah dan buah naga putih dibuat dengan metode maserasi dengan pelarut etanol 96\%. Dosis ekstrak buah naga merah dan ekstrak buah naga putih ditentukan peneliti dengan melakukan penelitian pendahuluan (preeksperimental) terhadap 3 variasi dosis, yaitu $30 \mathrm{mg} / 200 \mathrm{~g} \mathrm{bb} / \mathrm{hari}, \quad 60 \mathrm{mg} / 200 \mathrm{~g} \mathrm{bb} / \mathrm{hari}$ dan $120 \mathrm{mg} / 200 \mathrm{~g} \mathrm{bb} / \mathrm{hari}$.

Bedasarkan hasil penelitian pendahuluan (pre-eksperimental), dosis ekstrak buah naga merah adalah $60 \mathrm{mg} / 200 \mathrm{~g} \mathrm{bb} /$ hari merupakan dosis terbaik untuk menurunkan kadar kolesterol darah dan dosis ekstrak buah naga putih 120 $\mathrm{mg} / 200 \mathrm{~g} \mathrm{bb} /$ hari merupakan dosis terbaik untuk menurunkan kadar kolesterol darah.

Dosis Simvastatin yang digunakan dalam penelitian ini adalah $0,072 \mathrm{mg} /$ hari. Konstanta konversi dosis dari manusia $(70 \mathrm{~kg})$ ke tikus $(200$ g) adalah 0,018. Perhitungan dosis simvastatin yang digunakan dalam penelitian ini adalah 40 $\mathrm{mg} /$ hari x $0,018=0,72 \mathrm{mg} /$ hari.

Intervensi. Sampel dikelompokkan secara acak dalam 5 kelompok perlakuan, yaitu 1) Pakan standar+CMC 1\% (Kontrol Negatif/K1); 2) Pakan standar+telur puyuh $10 \mathrm{ml} / \mathrm{kgbb}$ (Kontrol Positif/K2); 3) Pakan standar+telur puyuh 10ml/ $\mathrm{kgbb}+$ simvastatin dosis $0,72 \mathrm{mg} /$ hari (P1); 4) Pakan standar+telur puyuh $10 \mathrm{ml} / \mathrm{kgbb}+$ Ekstrak naga merah dosis $60 \mathrm{mg} / 200 \mathrm{~g}$ bb/hari (P3); 5) Pakan standar+telur puyuh $10 \mathrm{ml} / \mathrm{kgbb}+$ Ekstrak naga putih dosis $120 \mathrm{mg} / 200 \mathrm{~g}$ bb/hari (P4). Sampel dipelihara dalam kandang individu dan diberikan nomor sesuai kelompok perlakuan.

Tikus pada awalnya diaklimatisasi selama tujuh hari dengan diberikan pakan standar dan minum aquades ad libitum (Lailani et al. 2013). Selanjutnya tikus diberikan perlakuan yang berbeda, yaitu kelompok kontrol negatif (K1) hanya mendapat pakan standar dan Na-CMC 1\%, kelompok kontrol positif (K2) mendapat pakan standar, telur puyuh $10 \mathrm{ml} / \mathrm{kgbb}$, dan $\mathrm{Na}-\mathrm{CMC}$ $1 \%$, kelompok perlakuan 1 (P1) mendapat pakan standar, telur puyuh $10 \mathrm{ml} / \mathrm{kgbb}$ dan Simvastatin dosis $0,72 \mathrm{mg} /$ hari, kelompok perlakuan 2 (P2) mendapat pakan standar, telur puyuh $10 \mathrm{ml} / \mathrm{kgbb}$ dan ekstrak buah naga merah dosis $60 \mathrm{mg} / 200 \mathrm{~g}$ bb/hari, kelompok perlakuan 3 (P3) mendapat pakan pakan standar, telur puyuh $10 \mathrm{ml} / \mathrm{kgbb}$ ekstrak buah naga putih dosis $120 \mathrm{mg} / 200 \mathrm{gbb} /$ hari. Perlakuan ini dilakukan selama 14 hari.

Pada hari ke 15, seluruh tikus dipuasakan selama 10 jam, lalu dilakukan prosedur pengambilan darah. Darah diambil dari vena kaudalis ekor tikus. Analisis darah yang dilakukan adalah analisis kadar kolesterol total dengan metode CHOD-PAP (Cholesterol Oxidase-Peroxidase Aminoantipyrine Phenol) menggunakan spektrofotometer pada panjang gelombang $500-550 \mathrm{~nm}$ (Biotec 2011).

Pemeriksaan kolesterol dilakukan sebanyak satu kali yaitu setelah pemberian induksi hiperkolesterol dan pemberian terapi. Sebelum pemeriksaan kolesterol, tikus ditimbang

\section{Pengolahan dan analisis data}

Data kadar kolesterol total dianalisis dengan metode One Way ANOVA pada tingkat kepercayaan $95 \%$. Jika hasil analisis menunjukkan perbedaan nyata antara kelompok kontrol dan kelompok perlakuan, maka dilanjutkan uji Post Hoc Bonferroni. Pengolahan data dan analisis data dilakukan menggunakan progam SPSS for Windows versi 18.0. 
Prakoso dkk.

\section{HASIL DAN PEMBAHASAN}

Tabel 1 merupakan data hasil penelitian pendahuluan (Pre-Eksperimental) yang dilakukan peneliti. Dosis $60 \mathrm{mg} / 200 \mathrm{~g}$ bb/hari pada ekstrak buah naga merah dan dosis $120 \mathrm{mg} / 200 \mathrm{~g}$ bb/hari pada ekstrak buah naga putih dipilih karena merupakan dosis terbaik dari tiga variasi dosis yang ada. Setelah mendapatkan dosis terbaik dari ketiga variasi dosis pada penelitian pendahuluan, peneliti melanjutkan penelitian eksperimen dengan masa penelitian selama 14 hari. Pengukuran kolesterol total menunjukkan hasil rata-rata yang bervariasi antara kelompok perlakuan dengan kelompok kontrol.

Tabel 2 merupakan rata-rata kadar kolesterol total tikus pada penelitian selama 14 hari. K1 merupakan kelompok kontrol negatif. K1 diharapkan menjadi batas kadar kolesterol normal pada penelitian ini. K2 merupakan kelompok kontrol positif dimana K2 memiliki kadar rata-rata kolesterol total tertinggi dibandingkan kelompok lain akibat induksi hiperkolesterol dengan menggunakan telur puyuh. P1, P2 dan P3 merupakan kelompok perlakuan. Kelompok P1, P2 dan P3 memiliki kadar kolesterol total yang lebih rendah dibandingkan kelompok K2 hal ini menunjukkan bahwa simvastatin, ekstrak buah naga merah dan ekstrak buah naga putih memiliki efek antihiperkolesterol.

Hasil analisis One Way ANOVA didapatkan nilai signifikansi alpha sebesar 0,001 $(p<0,05)$. Hal ini menunjukkan bahwa terdapat perbedaan rata-rata kadar kolesterol yang bermakna antar kelompok (Tabel 3).

Hasil analisis post-hoc menunjukkan perbedaan bermakna antara kelompok $\mathrm{K} 1$ dengan K2 dan antara kelompok K2 dengan P2 karena memiliki nilai signifikansi alpha kurang dari 0,05 $(\mathrm{p}<0,05)$. Sedangkan, hasil analisis post-hoc kelompok K2 dengan P1 dan P3 tidak menunjukkan perbedaan yang bermakna, karena memiliki nilai signifikansi alpha lebih dari 0,05 ( $\mathrm{p}>0,05)$.

Secara laboratoris, terdapat perbedaan kadar kolesterol total pada kelompok K2 dengan kelompok K1 sebesar 25,83 mg/dl. Kelompok $\mathrm{K} 2$ memiliki kadar kolesterol yang lebih tinggi dibandingkan kelompok K1.

Tabel 1. Hasil penelitian pendahuluan (pre-eksperimental)

\begin{tabular}{lc}
\hline \multicolumn{1}{c}{ Perlakuan } & Kadar kolesterol total (mg/dl) \\
\hline K1 (Kontrol negatif (Na-CMC 1\%)) & 98,0 \\
K2 (Kontrol positif (Induksi hiperkolesterol )) & 127,0 \\
P1 (Simvastatin dosis 0,72 mg/200g bb/hari) & 152,0 \\
P2 (Ekstrak buah naga merah dosis 30mg /200 g bb/hari) & 117,5 \\
P3 (Ekstrak buah naga merah dosis 60mg /200 g bb/hari) & 114,0 \\
P4 (Ekstrak buah naga merah dosis 120mg /200 g bb/hari) & 138,0 \\
P5 (Ekstrak buah naga putih posis 30mg /200 g bb/hari) & 118,0 \\
P6 (Ekstrak buah naga putih dosis 60mg /200 g bb/hari) & 103,0 \\
P7 (Ekstrak buah naga putih dosis 120mg /200 g bb/hari) & 91,0 \\
\hline
\end{tabular}

Tabel 2. Rata-rata kadar kolesterol total darah tikus

\begin{tabular}{lc}
\hline \multicolumn{1}{c}{ Perlakuan } & Kadar kolesterol total (mg/dl) \\
\hline K1 (Kontrol negatif. Tikus diberikan pakan standar dan Na-CMC 1\%) & $75,33 \pm 7,86$ \\
K2 (Kontrol positif. Tikus diberikan pakan standar dan telur puyuh 10ml/kgbb) & $101,16 \pm 12,79$ \\
P1 (Tikus diberikan pakan standar, telur puyuh 10ml/kgbb, dan Simvastatin & $91,67 \pm 15,25$ \\
0,72 mg/hari) & $75,33 \pm 6,34$ \\
P2 (Tikus diberikan pakan standar, telur puyuh 10ml/kgbb, dan Ekstrak buah \\
$\begin{array}{l}\text { naga merah 60mg/200 g bb/hari.) } \\
\text { P3 (Tikus diberikan pakan standar, telur puyuh 10ml/kgbb, dan ekstrak buah } \\
\text { naga putih 120mg/200 g bb/hari) }\end{array}$ \\
\hline
\end{tabular}


Tabel 3. Perbandingan kadar kolesterol total antar kelompok

\begin{tabular}{|c|c|c|c|c|}
\hline Kelompok & Kelompok & Rata-Rata $(\overline{\mathrm{x}})(\mathrm{mg} / \mathrm{dl})$ & Perbedaan rata-rata & $\mathrm{p}$ \\
\hline \multirow{4}{*}{$\begin{array}{c}\mathrm{K} 1 \\
\overline{\mathrm{x}}=75.33 \mathrm{mg} / \mathrm{dl}\end{array}$} & $\mathrm{K} 1$ & 101,16 & $-25,83333^{*}$ & 0,002 \\
\hline & $\mathrm{P} 1$ & 91,67 & $-16,33333$ & 0,118 \\
\hline & $\mathrm{P} 2$ & 75,33 & 0,00000 & 1,000 \\
\hline & & 89,67 & $-14,33333$ & 0,250 \\
\hline \multirow{4}{*}{$\begin{array}{c}\mathrm{K} 2 \\
\overline{\mathrm{x}}=101.16 \mathrm{mg} / \mathrm{dl}\end{array}$} & K1 & 75,33 & $25,83333^{*}$ & 0,002 \\
\hline & $\mathrm{P} 1$ & 91,67 & 9,50000 & 1,000 \\
\hline & $\mathrm{P} 2$ & 75,33 & $25,83333^{*}$ & 0,002 \\
\hline & P3 & 89,67 & 11,50000 & 0,672 \\
\hline \multirow{4}{*}{$\begin{array}{c}\mathrm{P} 1 \\
\overline{\mathrm{x}}=91.67 \mathrm{mg} / \mathrm{dl}\end{array}$} & K1 & 75,33 & 16,33333 & 0,118 \\
\hline & K2 & 101,16 & $-9,50000$ & 1,000 \\
\hline & $\mathrm{P} 2$ & 75,33 & 16,33333 & 0,118 \\
\hline & P3 & 89,67 & 2,00000 & 1,000 \\
\hline \multirow{4}{*}{$\begin{array}{c}\mathrm{P} 2 \\
\overline{\mathrm{x}}=75.33 \mathrm{mg} / \mathrm{dl}\end{array}$} & $\mathrm{K} 1$ & 75,33 & 0,00000 & 1,000 \\
\hline & $\mathrm{K} 2$ & 101,16 & $-25,83333^{*}$ & 0,002 \\
\hline & $\mathrm{P} 1$ & 91,67 & $-16,33333$ & 0,118 \\
\hline & P3 & 89,67 & $-14,33333$ & 0,250 \\
\hline \multirow{4}{*}{$\begin{array}{c}\mathrm{P} 3 \\
\overline{\mathrm{x}}=89.67 \mathrm{mg} / \mathrm{dl}\end{array}$} & K1 & 75,33 & 14,33333 & 0,250 \\
\hline & $\mathrm{K} 2$ & 101,16 & $-11,50000$ & 0,672 \\
\hline & P1 & 91,67 & $-2,00000$ & 1,000 \\
\hline & $\mathrm{P} 2$ & 75,33 & $-14,33333$ & 0,250 \\
\hline
\end{tabular}

Perbedaan kadar kolesterol secara statistik antara kelompok K1 dengan K2 menunjukkan hasil yang bermakna karena memiliki nilai signifikansi alpha kurang dari 0,05 $(\mathrm{p}<0,05)$. Perbedaan kadar kolesterol total ini sesuai dengan penelitian yang dilakukan Kusuma et al. (2016), yang menyatakan bahwa pemberian telur puyuh dosis $10 \mathrm{ml} / \mathrm{kgbb}$ dapat meningkatkan kadar kolesterol total secara signifikan dibandingkan kelompok kontrol negatif dalam waktu 14 hari. Kadar kolesterol total yang tinggi tersebut dikarenakan meningkatnya jumlah konsumsi asam lemak jenuh. Asam lemak akan diubah menjadi asetil KoA melalui oksidasi beta, sedangkan asetil KoA merupakan prekursor dari kolesterol. Peningkatan jumlah prekursor akan menyebabkan tingginya kadar kolesterol total (Kusuma et al. 2016).

hasil uji secara laboratoris, terdapat perbedaan kadar kolesterol total antara kelompok K2 dibandingkan dengan kelompok P1, P2, P3. Kadar kolesterol kelompok P1 lebih rendah dibandingkan kelompok K2. Hal ini menunjukkan bahwa pemberian simvastatin dosis $0,72 \mathrm{mg} /$ hari dapat menurunkan kadar kolesterol total darah pada kelompok P1. Simvastatin memiliki mekanisme penghambat enzim HMG-KoA reduktase secara kompetitif, sehingga menyebabkan penurunan sintesis kolesterol (Brunton et al. 2011).

Perbedaan kadar kolesterol secara statistik antara kelompok K2 dengan P1 tidak menunjukkan hasil yang bermakna karena memiliki nilai signifikansi alpha lebih dari 0,05 ( $>>0,05)$. Hal ini kemungkinan disebabkan karena simvastatin belum mencapai efek terapi maksimum pada pemberian selama 14 hari. Simvastatin dapat mencapai efek terapi maksimum pada minggu keempat sampai minggu keenam (Bryant \& Kathleen 2011).

Kadar kolesterol kelompok P2 dan P3 lebih rendah dibandingkan kelompok K2. Hal ini menunjukkan bahwa pemberian ekstrak buah naga merah dosis $60 \mathrm{mg} / 200 \mathrm{~g}$ bb/hari dan ekstak buah naga putih $120 \mathrm{mg} / 200 \mathrm{gbb} /$ hari dapat menurunkan kadar kolesterol total darah.

Kelompok P2 memiliki perbedaan rata-rata kadar kolesterol total yang lebih besar dibandingkan dengan kelompok P3 apabila dibandingkan dengan kelompok kontrol positif. Hal ini kemungkinan disebabkan adanya perbedaan kadar zat yang berperan dalam menurunkan kadar kolesterol darah diantara kedua spesies buah

Tabel 4. Rata-rata kadar kolesterol kelompok kontrol positif dibandingkan kelompok perlakuan

\begin{tabular}{ccc}
\hline Kontrol Positf & Kelompok perlakuan & Perbedaan rata-rata \\
\hline \multirow{3}{*}{$\mathrm{K} 2=101,16 \pm 12,79 \mathrm{mg} / \mathrm{dl}$} & $\mathrm{P} 1=91,67 \pm 15,25 \mathrm{mg} / \mathrm{dl}$ & $9,50 \mathrm{mg} / \mathrm{dl}$ \\
& $\mathrm{P} 2=75,33 \pm 6,34 \mathrm{mg} / \mathrm{dl}$ & $25,83 \mathrm{mg} / \mathrm{dl}$ \\
& $\mathrm{P} 3=89,67 \pm 6,56 \mathrm{mg} / \mathrm{dl}$ & $11,5 \mathrm{mg} / \mathrm{dl}$ \\
\hline
\end{tabular}


naga seperti antioksidan (betasianin, fenol, flavonoid dan vitamin $\mathrm{C}$ ), niasin, serat, asam lemak tidak jenuh, alkaloid, saponin dan titerpenoid.

Buah naga merah memiliki kandungan vitamin C sebesar 32,65 $\pm 1,59 \mathrm{mg}$, lebih besar daripada buah naga putih yang hanya $31,05 \pm 1,22$ mg (Choo \& Yong 2011). Vitamin C berperan dalam membantu reaksi hidroksilasi pembentukan garam empedu. Meningkatnya pembentukan garam empedu akan menyebabkan ekskresi kolesterol meningkat sehingga dapat menurunkan kadar kolesterol darah (Hapsari \& Kusumastuti 2014).

Buah naga merah memiliki kandungan serat pangan (dietary fiber) sebesar 3,2g/100g buah, lebih tinggi dibandingkan kandungan serat pangan buah naga putih yang hanya sebesar $1,1 \mathrm{~g} / 100 \mathrm{~g}$ buah (Mahattanatawee et al. 2006). Dalam saluran pencernaan serat dapat mengikat garam empedu (produk akhir kolesterol) kemudian dikeluarkan bersamaan dengan feses. Dengan demikian, serat pangan mampu mengurangi kadar kolesterol dalam plasma darah. Pada serat pangan yang larut air, akan dengan mudah terfermentasi. Produk hasil fermentasi serat pangan oleh bakteri usus, yaitu Short Chain Fatty Ac$i d s$ (SCFA) atau disebut juga asam lemak rantai pendek juga memiliki pengaruh terhadap penurunan kolesterol, yaitu dari pembentukan propionat, yang dapat menginhibisi enzim HMG-KoA reduktase, sehingga menghambat sintesis kolesterol (Fairudz \& Nisa 2015).

Buah naga merah memiliki kandungan vitamin B3 (niasin) yang lebih tinggi daripada buah naga putih yaitu sebesar $1,3 \mathrm{mg} / 100 \mathrm{~g}$ buah, sedangkan pada buah naga putih hanya sebesar 0,2 mg/100g buah (Pareira 2010 ; Liniawati 2011). Niasin menghambat lipolisis trigliserida oleh hormon sensitive lipase dalam jaringan adiposa sehingga mengurangi transpor asam lemak bebas ke hati dan menurunkan sintesis trigliserida. Penurunan sintesis trigliserida ini akan menyebabkan berkurangnya produksi VLDL (very low density lipoprotein) sehingga kadar LDL (low density lipoprotein) menurun. Selain itu, niasin juga meningkatkan aktivitas LPL (Lipoprotein Lipase) yang akan menurunkan kadar kilomikron dan trigliserida VLDL (Furi \& Wahyuni 2011).

Buah naga merah memiliki pigmen berwarna merah yaitu betasianin. Betasianin merupakan turunan dari betalain. Betalain telah diteliti manfaatnya sebagai antiradikal dan senyawa antioksidatif (Pertiwi 2014). Kandungan betalanin dalam buah naga merah dapat menekan produksi asam lemak rantai pendek dan mencegah peningkatan serum total kolesterol pada tikus dengan dislipidemia (Febriani et al. 2016). Buah naga merah memiliki aktivitas antioksidan yang lebih tinggi dibandingkan buah naga putih, dimana aktivitas antioksidan buah naga merah sebesar $134,1 \pm 30,1 \mu \mathrm{g} \mathrm{GA} / \mathrm{g}$ puree dan pada buah naga putih sebesar $34,7 \pm 7,3 \mu \mathrm{g}$ GA/g puree diukur dengan metode DPPH (Mahattanatawee et al. 2006).

Buah naga putih memiliki kandungan fenol total sebesar $28,65 \pm 1,79 \mathrm{mg}$ gallic acid $/ 100 \mathrm{~g}$ buah, lebih besar dibandingkan dengan buah naga merah yang hanya 24,22 $\pm 0,95 \mathrm{mg}$ gallic acid/100g buah (Choo \& Yong 2011). Senyawa fenol dapat berfungsi sebagai antioksidan karena kemampuannya meniadakan radikal bebas dan radikal perioksida sehingga efektif dalam menghambat oksidasi lipid (Susanti \& Panunggal 2015). Flavonoid adalah antioksidan eksogen yang telah dibuktikan bermanfaat dalam mencegah kerusakan sel akibat stres oksidatif. Flavonoid sebagai antioksidan secara langsung adalah dengan mendonorkan ion hidrogen sehingga dapat menetralisir efek toksik dari radikal bebas (Sumardika \& Jawi 2012).

Buah naga putih memiliki kandungan asam lemak tidak jenuh lebih besar dibandingkan dengan buah naga merah (Ariffin et al. 2009). Efek penurunan kadar kolesterol LDL oleh MUFA dan PUFA berkaitan dengan bertambahnya jumlah aktivitas reseptor LDL. Diet tinggi MUFA 20\% dari total kalori dapat menurunkan kadar kolesterol total 10\%, LDL 14\% dan Trigliserida 13\% (Wahyuningsih \&Wirawanni 2013).

Buah naga merah dan buah naga putih juga memiliki kandungan senyawa fitokimia yang berperan dalam menurunkan kadar kolesterol darah, yaitu senyawa alkaloid, saponin dan titerpenoid (Tabel 5). Senyawa alkaloid mampu menghambat kinerja enzim lipase dalam saluran cerna sehingga absorpsi lemak dalam tubuh berkurang (Budiarto et al. 2016). Efek utama saponin terhadap pencernaan lipid terlihat melalui efek asam

Tabel 5. Hasil uji fitokimia ekstrak buah naga merah dan buah naga putih

\begin{tabular}{lcc}
\hline Uji fitokimia & $\begin{array}{c}\text { Buah naga } \\
\text { merah }\end{array}$ & $\begin{array}{c}\text { Buah naga } \\
\text { putih }\end{array}$ \\
\hline Alkaloid & + & + \\
Saponin & + & + \\
Tanin & - & - \\
Fenolik & + & + \\
Flavonoid & + & + \\
Triterpenoid & + & + \\
Steroid & - & - \\
Glikosida & + & + \\
Sumber: Data primer peneliti dari BALITTRO, Bogor, \\
\multicolumn{2}{r}{ Jawa Barat (No.Adm.64/T/LAB/L/17). }
\end{tabular}

J. Gizi Pangan, Volume 12, Nomor 3, November 2017 
empedu. Saponin membentuk misel dengan asam empedu, akibatnya kemampuan asam empedu untuk membentuk misel dengan asam lemak berkurang (Bogoriani 2015). Terpenoid berperan dalam menghambat biosintesis kolesterol dengan mengatur degadasi enzim 3-hidroksi-3-metilglutaril (HMG-KoA) reduktase (Warditiani et al. 2015).

\section{KESIMPULAN}

Ekstrak buah naga merah dan ekstrak naga putih memiliki efek potensial dalam memperbaiki kondisi hiperkolesterolemia. Pemberian ekstrak buah naga merah dan ekstrak buah naga putih menunjukkan hasil kadar kolesterol total yang lebih rendah dibandingkan kelompok kontrol positif. Kelompok perlakuan ekstrak buah naga merah memiliki perbedaan kadar kolesterol total sebesar 25,83 $\mathrm{mg} / \mathrm{dl}$ sedangkan kelompok perlakuan buah naga putih memiliki perbedaan kadar kolesterol darah sebesar 11,5 mg/dl apabila dibandingkan dengan kelompok kontrol positif. Secara laboratoris terdapat perbedaan antara kadar kolesterol total tikus yang diberikan perlakuan ekstrak buah naga merah (Hylocereus polyrhizus) dengan kadar kolesterol total tikus yang diberikan perlakuan ekstrak buah naga putih (Hylocereus undatus), namun secara statistik tidak menunjukkan perbedaan yang bermakna $(\mathrm{p}>0,05)$.

Penelitian ini dapat diterapkan kepada masyarakat dengan kadar kolesterol darah yang tinggi sebagai pilihan alternatif diet. Tetapi, perlu dilakukan penelitian lanjutan mengenai efek buah naga terhadap profil lipid seperti LDL, HDL dan Trigliserida, guna menunjang terapi pada pasien dislipidemia sesuai dengan diagnosis bedasarkan profil lipid pasien.

\section{DAFTAR PUSTAKA}

Agustina. 2014. Pengaruh pemberian kitosan terhadap kadar Kolesterol total tikus (sprague-dawley) yang diberi pakan tinggi asam lemak Trans [Skripsi]. Bogor. Institut Pertanian Bogor.

[AHA] The American Heart Association. 2016. Coronary Artery Disease. Texas : American Heart Association.

Ariffin AA, Bakar J, Tan CP, Rahman RA, Karim R, Loi CC. 2009. Essential fatty acids of pitaya (dragon fruit) seed oil. Food Chemistry 114(2):561-564.

Biotec. 2011. Cholesterol (CHOD-PAP) En- zymatic Colorimetric Determination of Serum Cholesterol. Biotec Laboratory Equipment.

Bogoriani NW. 2015. Saponin Daun Andong (Cordyline Terminalis Kunth) Menurunkan Kolesterol Plasma Dengan Meningkatkan Ekskresi Kolesterol Dan Asam Empedu Feses Pada Tikus Wistar Serta Membentuk Kompleks Dengan Kolesterol Secara In Vitro [Disertasi]. Denpasar : Universitas Udayana.

Brunton LL, Chabner BA, Knollman BC. 2011. Goodman and Gilman'S the Pharmacological Basis of Therapeutics $12^{\text {th }}$ edition. New York: McGaw-Hill Medical.

Bryant B, Kathleen K. 2011. Pharmacology for Health Professionals $3^{\text {rd }}$ edition. Australia: Elsevier.

Choo WS, Yong WK. 2011. Antioxidant properties of two species of Hylocereus fruits. Advances in Applied Science Research 2(3):418-425.

Budiarto MA, Yuniwarti EYW, Isroli. 2016. Pengaruh pemberian tepung daun jati belanda (Guazuma ulmifolia L.) dalam pakan terhadap kadar trigliserida darah dan lemak abdominal ayam broiler. Bulletin Anatomi dan Fisiologi 1(1):43-47.

Fairudz A, Nisa K. 2015. Pengaruh serat pangan terhadap kadar kolesterol penderita overweight. Majority 4(8):121-126.

Febriani W, Sulaeman A, Setiawan B. 2016. Tepung buah naga merah dan olahraga memperbaiki glukosa darah dan profil lipid darah pada tikus obes. J Gizi Pangan 11(3):175-182.

Furi PR, Wahyuni AS. 2011. Pengaruh ekstrak etanol jamur Lingzhi (Ganoderma Lucidum) terhadap kadar HDL (High Density Lipoprotein) pada tikus dislipidemia. Jurnal Farmasi Indonesia PHARMACON 12(1):1-8.

Hapsari YT, Kusumastuti AC. 2014. Pengaruh Vitamin C Terhadap Kadar Low Density Lipoprotein (LDL) Lanjut Usia Setelah Pemberian Jus Lidah Buaya (Aloe Barbadensis Miller). Journal of Nutrition College 3(4):770-776.

Indriasari I. 2012. Ekstrak Ethanol Buah Naga Merah (Hylocereus polyrhizus) Memperbaiki Profil Lipid pada Tikus Wistar Jantan (Rattus norvegicus) Dislipidemia [Tesis]. Denpasar: Universitas Udayana.

Kristanto D. 2014. Berkebun Buah Naga. Jakarta: Penebar Swadaya. 
Kusuma AM, Asarina Y, Rahmawati YI. 2016. Efek ekstrak bawang dayak (Eleutherine palmifolia (L.)Merr) dan ubi ungu (Ipomoea batatas L.) terhadap penurunan kadar kolesterol dan trigliserida darah pada tikus jantan. Jurnal Kefarmasian Indonesia 6(2):108-116.

Lailani M, Edward Z, Herman R. 2013. Gambaran tekanan darah tikus wistar jantan dan betina setelah pemberian diet tinggi garam. Jurnal Kesehatan Andalas 2(3):146-150.

Liniawati MMV. 2011. Pemberian ekstrak buah naga merah (Hylocereus polyrhizus) menurunkan kadar F2 isoprostan pada tikus putih jantan (Albino Rat) yang diberi aktivitas berlebih [Tesis]. Denpasar: Universitas Udayana.

Mahattanatawee K, Manthey JA, Luzio G, Talcott ST, Goodner K, Baldwin EA. 2006. Total antioxidant activity and fiber content of select Florida-gown tropical fruits. Journal of Agicultural and Food Chemistry 54(19):7355-7363.

Pareira FMM. 2010. Pengaruh Pemberian Jus Buah Naga Putih (Hylocereus undatus H.) Terhadap Kadar Kolesterol Total Tikus Putih (Rattus norvegicus) [Skripsi]. Surakarta : Universitas Sebelas Maret.

Pertiwi WA. 2014. Pengaruh pemberian jus buah naga merah (Hylocereus polyrhizus) terhadap kadar HDL pria dislipidemia. Journal of Nutrition College 3(4):762-769.

Sumardika IW, Jawi IM. 2012. Ekstrak air daun ubi jalar ungu memperbaiki profil lipid dan meningkatkan kadar SOD darah tikus yang diberi makanan tinggi kolesterol. Jurnal Ilmiah Kedokteran Medicina 43(2):67-70.

Susanti TMI, Panunggal B. 2015. Analisis antioksidan, total fenol dan kadar kolesterol pada kuning telur asin dengan penamba- han ekstrak jahe. Journal of Nutrition Collage 4(2):636-644.

Syarif P, Suryoutomo B, Soeprapto, H. 2011, Deskripsi dan manfaat tanaman obat di pedesaan sebagai upaya pemberdayaan apotik hidup. Jurnal Ilmu Pengetahuan dan Teknologi Universitas Pekalongan 21(1):20-32.

Tang CS, Norziah MH. 2007, Stability of betacyanin pigments from red purple pitaya fruit (Hylocereus polyrhizus) : Influence of $\mathrm{pH}$, temperature, metal ions and ascorbic acid. Indonesian Journal of Chemistry 7(3):327331.

Warditiani NK, Indrani AAIS, Sari NAPP, Swasti IAS, Dewi NPAK, Widjaja INK, Wirasuta IMAG 2015, Pengaruh pemberian fraksi terpenoid daun katuk (Sauropus Androgynus (L.) Merr) terhadap profil lipid tikus putih (Rattus Novergicus, L.) jantan galur wistar yang diinduksi pakan kaya lemak. Jurnal Farmasi Udayana 4(2):66-71.

Wahyuningsih W, Wirawanni Y. 2013, Perbedaan pengaruh kacang tanah (Arachis hypogaea) rebus dan panggang terhadap kadar kolesterol total pada wanita hiperkolesterolemia. Journal of Nutrition Collage 3(1):206-212.

Wiyono S, Bantas K, Hatma RD, Soekirman SW. 2004, Hubungan Antara Rasio Lingkar Pinggang-Pinggul dengan Kadar Kolesterol pada Orang Dewasa di Kota Surakarta. Jurnal Cermin Dunia Kedokteran 143:4448.

WHO. 2009. Global Health Observatory (GHO) data. World Health Organization. http:// www.who.int/gho/ncd/risk_factors/cholesterol_text/en [diakses $1 \overline{1}$ September 2016]. 